\title{
Cikkismertetés: Az oltásellenes („anti-vax”) mozgalom az egészséget világszinten érintő 10 legfontosabb fenyegetés között (részlet az Egészségügyi Világszervezet 13. általános munkaprogramjából)
}

\author{
Article review: Anti-vax movement among 10 top threats to global health \\ (excerpt from the WHO 13th General Programme of Work)
}

Ismertetők: Gajdács Márió $₫$ Szegedi Tudományegyetem Általános Orvostudományi Kar, Klinikai Mikrobiológiai Diagnosztikai Intézet

Ismertetett cikk: Draft thirteenth general programme of work, 2019-2023 (World Health Organisation); pp. 9-24. ${ }^{1}$

Beküldve: $\quad$ 2019.01.17.

doi: $\quad$ 10.24365/ef.v60i1.402

Kulcsszavak: Egészségügyi Világszervezet; munkaprogram; oltásellenesség; fenyegetés; célkitǔzés

Keywords: WHO; General Programme of Work; vaccine resistance; threat; goals

Az Egészségügyi Világszervezet (WHO) Vezető Bizottságának 142. ülésén (WHO EB 142; 2018. január 22-27., Genf) elfogadta a 13. általános munkaprogramját (13 ${ }^{\text {th }}$ General Programme of Work; GPW 13). A program egy 5 évre szóló (2019-2023) tervezet, amely tartalmazza a WHO vezetőinek célkitűzéseit és elkötelezettségét az egészségesebb világ megteremtésére mindenki számára, emellett előirányoz bizonyos stratégiai változásokat a szervezeten belül, hogy a jövőben minél hatékonyabban tudja végrehajtani tevékenységét. Az Egészségügyi Világszervezet jelentése szerint az elmúlt évtizedekben jelentős lépéseket tettünk a globális egészség fejlesztésének tekintetében. A várható élettartam a világ számos részén megnőtt, 2016-ban 6 millióval kevesebb 5 éven aluli gyermek halt meg, mint 1990ben, és közel járunk a járványos gyermekbénulás eradikálásáhozi is. Az elért sikerek ellenére még számos megoldandó probléma áll fenn a globális egészség területén, a krónikus, nem fertőző betegségek prevalenciájátólii a környezetszennyezés problémájáig.
A jelentésben az Egészségügyi Világszervezet az oltásokkal kapcsolatos bizonytalanságot és az oltásellenességet is említi a világot érintő 10 legfontosabb fenyegetés között. Oltási bizonytalanságnak (vaccine hesitancy) nevezzük, ha a védőoltások elérhetőségük ellenére késedelemmel kerülnek beadásra, oltásellenességnek (vaccine refusal) pedig a védőoltások beadásának elutasítását saját vagy gyermekeink részére. Az oltásellenességen túl a WHO az alábbiakat jelölte meg, mint 2019-től prioritást élvező, megoldandó, a globális egészséget és egészségügyet érintő problémákat:

- Légszennyezés és klímaváltozás

- Krónikus nem fertőző betegségek

- Globális influenza pandémia

- Aszály, éhínség, háborúk és migráció

- Antimikrobiális rezisztencia

- Ebola és más potenciális járványt okozó vírusok (Zika, MERS-CoV, SARS)

- Súlyos hiányosságok az alapellátásban

- Dengue-láz

- HIV/AIDS

' kiirtás, teljes megszabadulás valamitől

ii előfordulási gyakoriság 
A jelen ismertetés kiemelten a védőoltások problémájával foglalkozik. A védőoltások megfizethető és hatékony eszközei számos betegség megelőzésének és terjedésük meggátlásának. Sőt, egyes becslések szerint a védőoltások nélkül évente 2-3 millióval nőne a globális mortalitás. Ennek ellenére a világ számos országában az emberek növekvő aránya visszautasítja a védőoltások felvételét mind önmaguk, mind gyermekeik részére. Ez megnehezíti a lakosság kritikus lefedettségi szintjének elérését, csökkenti az ún. „nyájimmunitást”, ami gyakoribb megbetegedéshez és járványok kitöréséhez vezethet. Legtipikusabb példaként hozható a kanyaró (Morbili) előfordulásának 30\%-os globális emelkedése, melyért nagyrészt az oltásellenesség tehető felelőssé. Az utóbbi évtizedben az oltásellenes mozgalmak (ún. „anti-vax movements”) számos országban gyökeret vertek. Ezen mozgalmak tagjai leggyakrabban a fejlett országokban élnek, ahol az oltások által kivédhető megbetegedések (pl. kanyaró, szamárköhögés) előfordulása tipikusan alacsony. Az oltások összetételével, mellékhatásaival és káros következményeivel kapcsolatos hamis és félrevezető információikat, anekdotikus történeteiket a legkülönfélébb internetes felületeken, közösségi média oldalakon, illetve egymás között terjesztik. Az Amerikai Járványvédelmi Központ (CDC) adatai szerint a legtöbb ajánlott védőoltás átoltottsága 2017-ben viszonylag stabil maradt a 19-35 éves kor közötti populációban az előző évekhez képest, azonban a nem oltottak aránya 2001 óta megnégyszereződött. Más országokban szintén romló tendenciák figyelhetők meg: Ausztráliában kb. 40,000 gyermek nem kapta meg a megfelelő oltásokat szüleik tiltakozása miatt, Romániában vallási okokra hivatkozva próbálnak kitérni az oltási kötelezettség alól, Olaszországban pedig 2018 óta már nem kötelezi az állam a szülőket az oltási státusz igazolására gyermekeik iskolába való beiratkozása előtt.

\section{TANULSÁGOK A HAZAI SZAKEMBEREK SZÁMÁRA}

Magyarország a szigorú népegészségügyi előírásoknak és tevékenységeknek (házigyermekorvosi, védőnői preventív szolgálat) köszönhetően élen jár az életkorhoz kötött kötelező védőoltások beadásában. Az átoltottság aránya a gyerekeknél csaknem 100 százalékos, emellett az ajánlott oltások területén is igen jó eredményeket értünk el. Ennek ellenére nem lehetünk teljesen nyugodtak, hiszen az oltáselleneségi mozgalmak hazánkban is jelen vannak, és idővel teret hódíthatnak. A szülőket mindenképp meg kell győzni a megelőző védelem fontosságáról. A környező és távolabbi, kevésbé szigorú oltási rendszerrel rendelkező országokból (Szerbia, Románia vagy tengeren túli országok) érkező személyek esetén az egészségügyi dolgozóknak tisztában kell lenniük a behurcolható betegségek rizikójával, hosszabb tartózkodás, illetve letelepedés esetén pedig szorgalmazniuk kell a hazai oltási rend szerinti kötelező védőoltások beadását is.

\section{KÖSZÖNETNYILVÁNITÁS}

A közlemény létrejöttét az NTP-NFTÖ-18-C-0225 „Nemzet Fiatal Tehetségeiért Ösztöndíj” támogatta.

\section{HIVATKOZÁSOK}

\footnotetext{
${ }^{1}$ http://apps.who.int/gb/ebwha/pdf files/WHA71/A71 4-en.pdf?ua=1
} 